\title{
LETTER
}

\section{Methodology of electrical impedance tomography-derived measures of regional lung ventilation}

\author{
Inéz Frerichs", Tobias Becher and Norbert Weiler \\ See related research by Blankman et al., http://ccforum.com/content/18/3/R95
}

In the previous issue of Critical Care, we read with interest the article by Blankman and colleagues [1], who studied the performance of various electrical impedance tomography (EIT)-derived measures in detecting the 'best' positive end-expiratory pressure. The aim of that study is relevant; however, the article contains some methodological inaccuracies that need to be clarified.

One of the EIT measures used to characterize ventilation distribution is the center of ventilation $(\mathrm{COV})$, first introduced in [2]. The authors refer appropriately to an article that contains a methodological figure illustrating how COV is derived from EIT ventilation images [3]. However, the authors incorrectly state that COV is the ratio between the EIT-derived ventilations in the dorsal and whole-image regions, provide a wrong equation 6 , and attribute it to [3].

It is important for the understanding of EIT findings to appreciate that Figure one [1] does not show images of 'impedance' and the degree of 'aeration' (legend) but of tidal impedance differences representing regional tidal volumes. Regional ventilation delay (RVD) was analyzed not in [4], but in [5], where it was calculated in each pixel. A two-dimensional map was produced from these values, and standard deviation was calculated as an aggregate measure of ventilation homogeneity. Equation 3 regarding RVD calculation was used in [5], not in [6], where an additional multiplication by maximum impedance amplitude of the studied low-flow inflation was included. It is not clear which percentages of regional compliance are presented in Figure two B [1].

\footnotetext{
*Correspondence: inez.frerichs@uksh.de

Department of Anaesthesiology and Intensive Care Medicine, University

Medical Centre Schleswig-Holstein, Campus Kiel, Arnold-Heller-Str. 3, D-24145 Kiel, Germany
}

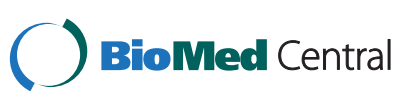

(c) 2014 Frerichs et al.; licensee BioMed Central Ltd. This is an Open Access article distributed under the terms of the Creative Commons Attribution License (http://creativecommons.org/licenses/by/4.0), which permits unrestricted use, distribution, and reproduction in any medium, provided the original work is properly credited. The Creative Commons Public Domain Dedication waiver (http://creativecommons.org/publicdomain/zero/1.0/) applies to the data made available in this article, unless otherwise stated.
EIT is currently at an important stage of its development. Its clinical use might be fostered by implementation of accurate analysis tools.

\section{Abbreviations}

COV: Center of ventilation; EIT: Electrical impedance tomography; RVD: Regional ventilation delay.

\section{Competing interests}

IF has received congress fees, travel costs, and speaking fees from CareFusion (Höchberg, Germany), Swisstom (Landquart, Switzerland), and Dräger (Lübeck, Germany), respectively. TB has received congress fees, travel costs, and speaking fees from Dräger. NW has received speaking fees and research grants from Dräger.

Published online: 18 November 2014

\section{References}

1. Blankman P, Hasan D, Groot Jebbink E, Gommers D: Detection of 'best' positive end-expiratory pressure derived from electrical impedance tomography parameters during a decremental positive end-expiratory pressure trial. Crit Care 2014, 18:R95.

2. Frerichs I, Hahn G, Golisch W, Kurpitz M, Burchardi H, Hellige G: Monitoring perioperative changes in distribution of pulmonary ventilation by functional electrical impedance tomography. Acta Anaesthesio/ Scand 1998, 42:721-726.

3. Frerichs I, Dargaville PA, van Genderingen $H$, Morel DR, Rimensberger PC: Lung volume recruitment after surfactant administration modifies spatial distribution of ventilation. Am J Respir Crit Care Med 2006, 174:772-779.

4. Zhao Z, Steinmann D, Frerichs I, Guttmann J, Moller K: PEEP titration guided by ventilation homogeneity: a feasibility study using electrical impedance tomography. Crit Care 2010, 14:R8.

5. Muders T, Luepschen H, Zinserling J, Greschus S, Fimmers R, Guenther U, Buchwald M, Grigutsch D, Leonhardt S, Putensen C, Wrigge H: Tidal recruitment assessed by electrical impedance tomography and computed tomography in a porcine model of lung injury. Crit Care Med 2012, 40:903-911.

6. Wrigge H, Zinserling J, Muders T, Varelmann D, Gunther U, von der Groeben C, Magnusson A, Hedenstierna G, Putensen C: Electrical impedance tomography compared with thoracic computed tomography during a slow inflation maneuver in experimental models of lung injury. Crit Care Med 2008, 36:903-909.

doi:10.1186/s13054-014-0635-5

Cite this article as: Frerichs et al:: Methodology of electrical impedance tomography-derived measures of regional lung ventilation. Critical Care 2014 18:635. 